http://journals.ums.ac.id/index.php/ijolae

\title{
Providing Equity of Access to Higher Education in Indonesia: A Policy Evaluation
}

\author{
Ihsan Fadhil ${ }^{1}$, Amra Sabic-El-Rayess ${ }^{2}$ \\ 1,2 Teachers College, Columbia University, USA
}

DOI: 10.23917/ijolae.v3i1.10376

Received: February $25^{\text {th }}, 2020$. Revised: April 13 $3^{\text {th }}, 2020$. Accepted: April 17 $7^{\text {th }}, 2020$

Available Online: April $20^{\text {th }}, 2020$. Published Regularly: January $1^{\text {st }}, 2021$

\begin{abstract}
In the last decade, Indonesia has worked towards expanding access to higher education, but the enrolment of the poor remains negligible with the majority of students in the country's leading public universities still coming from Indonesia's wealthiest echelons. Concerned with the issue of equity and access, the govern-ment has formulated a new policy calling on all higher education institutions to ensure at least $20 \%$ of their newly admitted students are of a low socioeconomic status (SES). The principal challenge the government has faced is a discrepancy between its ambitious political agenda and the policy's implementation affected by inadequate budgeting, lacking implementation mechanisms, and limited award allocations. This challen-ge raises a question of whether the Equity and Access Policy can be effectively implemented and, if so, under what conditions can such success be achieved. We thus examine the country's Equity and Access Policy, education system with its leadership structure, broader institutional framework, and how these fac-tors interact to obstruct the higher education access for the poor in Indonesia. The inadequate policy imple-mentation can impede Indonesia's human capital development and the country's economic growth.
\end{abstract}

Keywords: access, equity, financial aid, higher education, policy implementation

Corresponding Author:

Amra Sabic-El-Rayess, Teachers College, Columbia University, USA

Email:as2169@tc.columbia.edu

\section{Introduction}

In the last decade, the Indonesian government has pushed to improve access to higher education, resulting in the gross enrolment rates increasing from $17.23 \%$ in 2005 to $36.31 \%$ in 2018 (World Bank, 2019). However, the enrolment of the poor has remained low especially in the country's top public universities. In 2010 , only $2.5 \%$ of those enrolled at a higher education institution were from the poorest $20 \%$ of the households as compared with $64.7 \%$ of the student body coming from the wealthiest $20 \%$ of Indonesia's households (MOEC, 2013). Concerned with the issue of equity, the government created a new policy Law 12/section 74 (thereafter, the Equity and
Access Policy) - calling on all higher education institutions (HEIs) to enroll at least 20\% of its students from low socioeconomic backgrounds and tasking the Directorate General for Higher Education with its implementation (DGHE).

The primary challenge to this policy's implementation is that both public and private HEIs have the autonomy in budgeting and funding allocations. DGHE's jurisdiction over HEIs is limited to a supervisory role via each university's Board of Directors. This has created a tension between the government's ambitious political agenda and the lacking implementation mechanisms, including but not limited to the inadequate budget tracking 
and award allocations to the poor students. This challenge raises a question of whether the Equity and Access Policy can be effectively implemented. Thus various structural and organizational factors to determine whether and how they work to obstruct the policy's implementation are evaluated.

Conceptually, the study addresses the issues of educational equity, social justice, and economic development. We analyze one of the most pervasive problems of higher education globally: limited access to higher education by the poor. If higher education provides merited social mobility (Sabic-El-Rayess, 2012, 2013 \& 2016; Turner, 1960) and improves human capital (Schultz, 1961 \& 1981; Prakhov, 2019) then it is in the interest of each nation to promote mobility of the poor through education. But, as prior research has found (Sabic-El-Rayess, 2012, 2014 \& 2020; Sabic-El-Rayess \& Mansur, 2016; Sabic-ElRayess \& Seeman, 2017; Sabic-El-Rayess \& Otgonlkhagva, 2012; Sabic-El-Rayess, Mansur, Batkhuyag \& Otgonlkhagva, 2019; Moratti and Sabic-El-Rayess, 2009a and 2009b), the elite mechanisms and interests often prevail over those of the poor and are at play in most social, economic, educational and political hierarchies globally. Instead of broadening access, higher education typically serves to reproduce the existing social strata (SabicEl-Rayess \& Mansur, 2016) unless there is political will to interrupt the status quo and expand the access to the poor. To examine whether the political will to transform and improve equity and access to higher education in Indonesia is genuinely there, the design and implementation of the Equity and Access Policy is evaluated.

This evaluation is situated into a larger debate on access and equity in higher education, and our findings are contextualized within Foucault's (1997) social justice and ethics framework that calls on researchers to question all assumptions (Sabic-El-Rayess et al., 2019; Foucault, 1997). The assumption here is that the narrative around the Equity and Access Policy aims at broadening access for the poor, but that discourse may conflict with the implementation. There are other examples of education policies where the outcomes not only diverged from broadening access to education but instead adversely impacted the poor. For instance, the school uniform policy in Mongolia aimed at easing the access to education for the poor, but once implemented, it led to higher dropout rates amongst the poor (Sabic-El-Rayess et al., 2019; Sabic-El-Rayess \& Otgonlkhagva, 2012). Thus we question and probe the Equity and Access Policy to determine if and what factors prevent it from achieving the intended outcome for the poor in Indonesia.

We also recognize that providing financial aid to poor students can burden HEIs. In 2016, four years after the implementation of the Equity and Access Policy, poor students made up only $10 \%$ of Indonesia's total higher education enrolment (Directorate General for Higher Education, 2017). The federal government funds allocated differ greatly across HEIs in Indonesia, and there is no specification on how much of the federal funds the individual institutions are entitled to, which elevates the risk of corruption, misallocation of funds, and subjective decision-making that can, intentionally or not, affect the poor's access to HEIs (Welch, 2012). Corruption in education has been studied extensively as a barrier to merited social mobility, inclusion, and economic development (Sabic-El-Rayess, 2009, 2011, 2016a \& 2019). Systemic corruption has also been identified to trigger students' disengagement and even radicalization (Sabic-El-Rayess, 2016b and 2020; Sabic-ElRayess \& Mansur, 2020). Thus, sufficient and effective allocation of funds is essential to success of any policy. We end with a 
University of Gadjah Mada (UGM) case study as UGM is one of the nation's leading public universities. The inadequate policy implementation, we ultimately argue, can impede Indonesia's human capital development and the country's economic growth.

Indonesia consists of over 17,000 islands, and with its 260 million people ranks as the world's 4th most populous country. It is abundantly rich in natural resources but lacks in human capital with many Indonesians not advancing their knowledge and skills due to their poverty or the underdeveloped educational infrastructure in the regions of Indonesia where they reside. The country's current level of public education spending stagnates at $3.6 \%$ of GDP and is lower than what is advisable for developing economies (Dilas, Mackie, Huang \& Trines, 2019).

Access to and availability of HEIs is still limited in underdeveloped areas of Indonesia, forcing many individuals to move to cities to obtain education (OECD, 2013). Transportation and relocation costs are additional costs and the entry barriers for the poor (Logli, 2016). Despite these obstacles, the demand for higher education has increased over the years and total enrollment has grown by $68 \%$, from 3.7 million in 2006 to over 6.1 million in 2016 (WES, 2019). Secondary school graduation rates have also improved from $61.7 \%$ in 2013 to $65.9 \%$ in 2017 (OECD, 2020), stimulating demand for higher education.

Here, we define the higher education as all post-secondary schooling including vocational, academic, or professional type of schooling. HEIs - from academies, polytechnics, colleges, institutes to universities - provide various programming for their students. The number of these institutions has grown rapidly over the last couple of decades with most growth occurring in the private sector (Moeliodihardjo, 2014). Of 3,200 institutions, 92 are public and therefore governmentally managed (OECD/ADB, 2015). Public institutions are differentiated based on their accreditation and level of autonomy in governance and financing. The Ministry of Education and Culture (MOEC) along with DGHE regulates most public institutions, but some have their by-laws approved by the MOEC and the President. The implication of this is that, for most public institutions, the budget and related indicators are set by the MOEC to ensure that the institutions' individual strategies are closely aligned to their national agenda (Negara \& Benveniste, 2014). Stateowned HEIs are typically more autonomous relative to other public universities. They have independent sources of revenue and are more accountable to the public than the MOEC (Yulianto, 2017). Private HEIs have expanded access to higher education as well: they account for over $60 \%$ of enrolment nationally (OECD/ADB, 2015).

The urban-rural gap in provision of higher education remains significant. Only few provinces are home to $80 \%$ of top HEIs (Logli, 2015). For instance, the best 10 universities are located on the island of Java (QS, 2019). In 2012, the gross enrollment rate for higher education in Indonesia's capital, Jakarta, was $122 \%$, as compared to West Papua's meager 22\% (OECD, 2013). The growth in higher education needs to occur across all regions in Indonesia to meaningfully diversify access. In an effort to broaden that access, the DGHE has set out to establish community colleges with vocational programs in all districts of Indonesia (OECD/ADB, 2015). As of 2013, 35 community colleges were being developed in rural Indonesia (Logli, 2016). The government intends to build additional technical institutions outside Java along with 
the institutes of technology in the islands of Sumatra and Kalimantan as well as additional polytechnics in every province (OECD, 2013).
Despite challenges, demand for higher education remains high from all social quintiles, partly due to higher rate of graduation from secondary schooling (Figure $1)$.

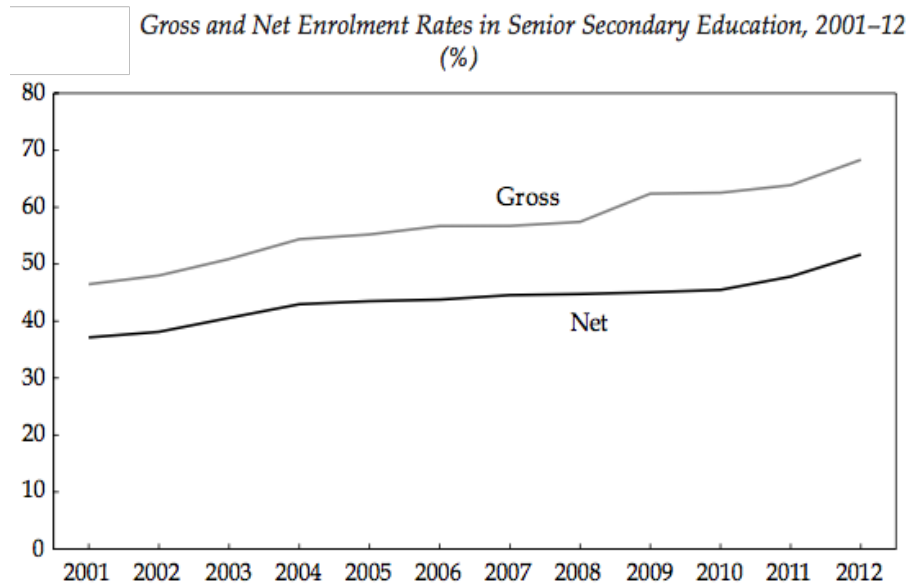

Figure 1. Indonesia's Senior Secondary Education Gross and Net Enrolment Rates 2001-2012 (Source: MOEC, 2013, p. 41)

Most institutions are currently located in Java (43.7\%) and Sumatra (29.1\%) groups of islands while the underdeveloped provinces of Maluku and Papua islands host only 3.4\% of all HEIs (Moeliodihardjo, 2014).
Consequently, the increase in the higher education graduation rates has largely been limited to Java and Sumatra island groups (Figure 2).

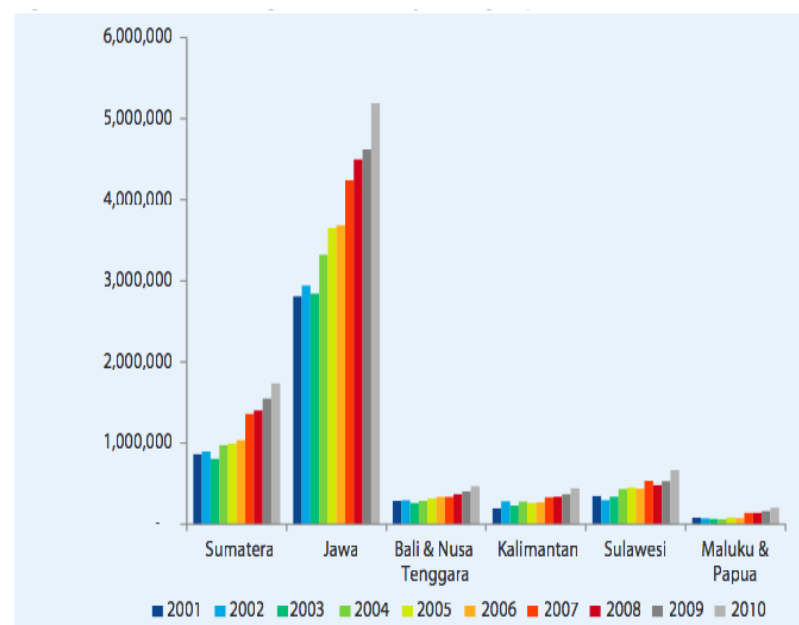

Figure 2. Labor Force with Higher Education by Island Group, 2001-2010

(Source: MOEC, 2014, p. 24)

The urban-rural gap in the number of institutions available correlates to the stark difference in the university educational attainment amongst the individuals living in the urban versus rural areas, with higher education attainment rates at $10.42 \%$ and 2.97\%, respectively (OECD/ADB, 2015). The higher education graduates are increasingly joining the urban labor force while the number of employees with higher 
education in rural areas has more than doubled in percentage terms (MOEC, 2014). The returns to education in rural areas have declined but can, in part, be explained by the lower growth rate in the labor force in rural regions overall ((MOEC, 2014). Another possible explanation for the urban-rural difference in returns is in the type of earnings. Urban earnings are typically obtained through salary, whereas workers in rural areas earn agricultural income (Van Cao and Akita, 2008). To ensure that earnings in rural areas expand to other industrial sources, different skills must be learned, which necessitates higher education expansion.

Access to higher education consistently benefits the elites. The majority of higher education students are from the two richest quintiles in Indonesia (MOEC, 2014). At least $80 \%$ of what Indonesia spends on higher education enriches the experience of the wealthiest $40 \%$ while more than $60 \%$ of it benefits the wealthiest $20 \%$ : in other words, the current public funding structure in Indonesia helps those who are already doing well (Gao, 2015). This parallels the obvious lack of support for the poor students expectedly compelling them to opt out of higher education, in favor of either technical or vocational training. Those less able to afford higher education are more likely to enroll in lower quality degree programs, consequently obtaining the lesser returns in the labor market (Gao, 2015). Yet, their broader participation in higher education is critical for producing a more qualified labor force that would advance Indonesia's economy.

The human capital theory (Schultz, 1961 $\&$ 1981) points to the formal education's role in increasing the labor productivity and producing various benefits, individual and societal. Though the higher education return for an individual is economically quantifiable via wages and lifetime earnings (Schultz, 1961; Becker, 1964), investing in people via education additionally provides measurable non-pecuniary benefits to health, fertility, consumption, savings, behavior and societal participation (Hartog \& Oosterbeck, 1998; Doyle \& Weale, 1994; Solmon, 1975; Becker, 1993; Tran, 2019). The social benefits and spillover effects are regularly reflected in improved public health, lesser crime and poverty, use of technology, and extended benefits to democracy, human rights, political stability, and environment (McMahon, 2010).

Financial aid programs have been deployed successfully in the established higher education systems to assist financially disadvantaged in accessing higher education. In the US, the 1965 Higher Education Act (HEA) was enacted with the objective to strengthen the college and university funding. The conventional human capital theory of how the student aid works is seeded in the belief that individuals behave rationally and make decisions "that maximize their expected happiness, or 'utility' over time" (GoldrickRab et al., 2009). The authors go on to suggest that in lieu of the short-term income, college graduates improve their longer term consumption and leisure given that higher education provides not only pecuniary but also numerous non-pecuniary benefits. The financial aid programs that resulted from the HEA have increased enrolment, college choice, and completion rates for the financial aid students (Dynarski \& Scott-Clayton, 2013; Dynarski, 2003; Klaauw, 2002). This expansion of higher education access has helped equalize the college costs for all thus ultimately benefiting the economic growth in the United States. 


\section{Method}

a. Key Stakeholder

Indonesia is a democratic government in a multi-party system. In 2019, there were officially 27 political parties participating in the General Election (Andayani, 2017). The presidential and vice presidential candidates work to garner enough support from other political parties to win in the election and create a governing coalition. Once they win, these political parties control the key positions in the government, making them influential in the policy making process.

Several ministries help govern HEIs in Indonesia, such as the Ministry of Religious Affairs (MORA), Ministry of Research, Technology and Higher Education (MORTHE), and Ministry of Finance (MOF). Under MORTHE, higher education affairs are managed by the DGHE. This specific ministry oversees HEIs except for the religious institutions that are monitored by the MORA while other governmental institutions oversee the 82 tertiary education service institutes in charge of training personnel in governmental ministries (OECD/ADB, 2015). The Ministry of Finance approves the budget for higher education mostly through the DGHE, primarily supporting the public higher education with only $8 \%$ to $10 \%$ of the overall funding being used for the private institutions (OECD/ADB, 2015).

The MORTHE through DGHE influences institutional leaders in higher education. Government Regulation 66/2010 specifies the governing structure of public HEIs, with four entities playing a key role: the Rector who manages the individual institution and chairs the Senate, the Senate that is responsible for academic affairs, the Oversight Unit that oversees all non-academic and financial matters, and the Advisory Board that assists with non-academic issues (World Bank, 2014). The Senate decides on the pool of candidates for a Rector position though the Minister of Education and Culture holds more than one third of all voting rights on who ultimately gets that job (DIKTI, 2017).

The Rector along with the Minister of MORTHE has the most influence and control over the management and operations of public HEIs. The Senate is the most powerful entity, but limited in its independent decision making given that it is overseen by the Rector, who works closely with the Minister (Gao, 2015). The Oversight Unit and the Advisory lack sufficient power that would secure HEIs accountability to stakeholders and the public (Gao, 2015). Therefore, while public institutions have different levels of autonomy in governance, operations and finance, their actions remain influenced by the ministries. Without more autonomous and independent managers and leaders in the higher education structure of Indonesia, it may be challenging to formulate and successfully implement effective policies.

\section{b. Agenda Setting}

Indonesia lacks in the number of qualified STEM professionals, triggering a dependency for partnerships with foreign companies that manage Indonesia's natural resources and technological growth. The World Bank (2010) has underscored Indonesia's need for trained labor with the country currently in demand of at least 50,000 engineers annually, but that number is expected to double by 2025 (ICEF Monitor, 2014). When everyone regardless of their background or economic circumstances is able to access higher education, they will contribute productively to the economy, which is why a comprehensive system of financial aid in the HEIs is integral in providing equity and access. This realization is one of the main forces behind the Equity and Access Policy. 
The current movement to improve the higher education system in Indonesia originated as part of the National MediumTerm Plan (NMTP) for 2010-2014. The plan details the Indonesian President's agenda stemming from the National Long-Term Development Plan for 2005-2025 (Republic of Indonesia, 2010). The long-term plan is comprehensive and contains insights on the national development strategy, various policies and programs (Republic of Indonesia, 2010). In line with the long term vision for the country, the NMTP aimed at broadly reforming Indonesia's economy by improving the quality of human resources, particularly in sciences and technology (Republic of Indonesia, 2010).

To fulfill this ambitious goal requires the development of Indonesia's higher education sector. In 2015, relative to Vietnam (28.54\%), Lao People's Democratic Republic (14.97\%), and the Philippines (35.48\%), Indonesia's 2015 enrolment in HEIs was higher, but at only $36.31 \%$ it was also behind that of Malaysia (45.13\%) and Thailand (49.29\%) (OECD/ADB, 2015). Indonesians who are 25 to 64 have low higher education attainment relative to Thailand, Singapore, and South Korea with only $4.6 \%$ of Indonesia's 2010 workers holding a university degree (DIKTI, 2016) Furthermore, the country is behind Thailand, Philippines and Malaysia in the labor productivity domain (OECD/ADB, 2015).

The main development target in higher education under this agenda was to increase the gross enrolment rate at universities of individuals who are 19 to 23 years of age from $21.26 \%$ in 2008 to $30 \%$ in 2014 (DIKTI, 2016). To reach this target, Indonesia hoped to provide affordable quality higher education throughout the nation. But, meeting this target requires not only cooperation from MORTHE but also collaboration with other ministries that have their own training programs at tertiary education service institutes. The coalitions of political parties that control the ministries also play a critical role in implementing this agenda.

Previous reforms aimed at ensuring the quality and access to higher education across the country. The first Law regarding higher education was enacted in 1961 and is still in effect now, requiring that at a minimum one public university in each of the provinces broadens access to higher education across Indonesia (Brewis, 2016). In 1996, as part of the Long-Term Education Plan, the MOEC worked towards both more autonomous and accountable institutions as well as improved accreditation and evaluation processes (World Bank, 1998). The Government Regulation on the Implementation of State Universities as Corporate Bodies (1999) led to four top state universities becoming more autonomous and gaining financial and academic autonomy via independent revenue generation, research structure, independent programming, and overall more autonomous management (Brewis, 2016). The author further suggests that the Government Regulation on Management and Governance of Education 2010 spelled out both management and policymaking frameworks at the national level.

The Higher Education Law 12/2012 (Republic of Indonesia, 2012) defined an ambitious agenda for higher education to serve as a foundation to the nation's intellectual, scientific and technological advancement and competitiveness globally and, in doing so, advance equity in access to higher education (OECD \& ADB, 2015). More importantly, this law is the first to specifically include an equity and inclusion centered policy for the admissions process in the effort to ensure access for the individuals from the lowest SES group. As part of the 
initiative to ensure broadly accessible higher education in all parts of the country, the government has included section 74 in the Higher Education Law 12 which states that higher education institutions must allocate $20 \%$ of the total enrolments across study programs for students who have high academic potential but come from low economic backgrounds and "frontier, outer and disadvantaged areas" (Republic of Indonesia, 2012).

\section{c. Policy Implementation: Top-Down vs Bottom-UP Approach}

Every policy is implemented in stages, and various actors often exert their influence before policy outputs are decided upon. Sabatier \& Mazmanian (1989) argue implementation often involves initiating action via court, executive or statutory decision. Further, they suggest the process may involve passing the basic statute, deciding on policy outputs, and aligning the implementation steps to the policy goals to minimize discrepancies between the actual impact and the intended effect, which can at times lead to additional revisions to the implementation process. As per Hjern (1993, p. 250): "[t]he implementation process is structured through a policy network, which is composed of interconnected clusters of firms, governments and associations, termed the implementation structure."

The existing implementation models are still debated with two polarizing schools of thought of the top-down versus the bottom-up model: Sabatier (1986) categorized these approaches by differentiating how their implementation begins and how their effectiveness is measured. Top-downers begin their analyses at the top of the implementation process and structure, focusing more on the policymakers' (top government officials) perspectives, interests, and goals, then move down to analyze the implementation at the operational level, particularly the behavior of the implementing officials. Implementation is understood as making lower-level officials take actions that materialize the intent of a formally adopted policy (Smith \& Larimer, 2008). It is deemed to be effective and successful if the policy objectives set by those at the top are attained at a reasonable cost.

Bottom-uppers begin their analyses from the bottom of the implementation process and structure, focusing on the perspectives, interests, demands, conflicts, and strategies of stakeholders at the operational level ('streetlevel officials') (Lipsky, 1980). This format allows lower-level officials to negotiate the changes by introducing new regulations or changes stemming from the experiments within the target population (Smith \& Larimer, 2008). With both approaches, the success is equated to a policy problem being solved.

\section{d. Blended Top-Down Approach}

The Equity and Access Policy was designed using a blended top-down approach, synthesizing both perspectives. This strategy, suggested by Sabatier \& Mazmanian (1980), uses the strengths of both approaches and addresses their weaknesses. The authors propose the following six pre-requisites for effective policy implementation: 1. well defined policy objectives; 2 . solid theoretical backing of policy in question; 3. legal structure to ensure compliance by all stakeholders; 4 . skilled implementation personnel; 5. broad policy support amongst powerful players; and 6. favorable socioeconomic context that maintains feasibility and political support for the policy.

In building this approach they rightly accounted for the concerns of the bottom-uppers (Lipsky, 1980; Elmore, 1979) regarding the politicians' dominion over policy implementation as well as the necessity of having well trained personnel at all levels of policy 
implementation. Both legal and political mechanisms must be in place to direct and restrain behaviors of the involved officials and other parties (Sabatier \& Mazmanian, 1980). It is for this reason that the blended top-down model cannot be defined as a purely top-down approach since it recognizes the relevance of the complex political and legal power structures at local levels as well. We employ this approach to assess the Equity and Inclusion Policy by considering the government and political system, relevant legislation and skills of the government officials.

The approach also recognizes that policy implementation does not occur in a political or power vacuum, at any level of the power structure. It is essential to understand the power dynamics amongst various stakeholders at all levels to gauge the policy's potential for a successful implementation. As Sabic-ElRayess and Mansur (2019, p. 9) note, policy goals "can be appropriated by less than altruistic actors...for their gain." In the absence of proper implementation mechanisms, deviations from the planned path can occur and risk a failed implementation.

In democratic countries, policymaking and implementation activities often consider the perspectives of the policy stakeholders and assess the conditions for implementation at all levels. Bottom-up approaches may be more relevant in analyzing the implementation process in democratic regimes where a diverse pool of actors engage in the implementation process (Brata, 2014). Top-down theoretical models elucidate the implementation process in an authoritarian regime where the power and control are centralized (Brata, 2014). Still, many policies in democratic contexts are implemented using the top-down approach while some aspects inherent to the bottom-up approaches are considered. In the case of Indonesia, evaluating the policy implementation process requires understanding the perspectives, interests and goals of the policymakers at the top level as well as those of the implementers at the bottom of the implementation structure. Sabic-El-Rayess and Mansur (2019, p. 13) agree with Foucauldian perspective that "power is not always structural, but rather present in all around us" further suggesting that poorly implemented policies only further "embed the class hierarchies more deeply into the mindsets of the poor."

Indonesia has transitioned in the last 15 years, after decades of authoritarian regime, into a more decentralized state, where the country's political reforms localized power along with financial resources that are now more broadly distributed to the regencies, municipalities and provinces (Nasution, 2016). The author further suggests that local communities are increasingly responsible for actions in the arena of health, education, public works, environment, transport, and economy. During such transitional process, the state's growing bureaucratic capacity has been essential to achieving greater economic development and securing broader autonomy of the state (Addison, 2009). Weak bureaucracy is a barrier to a policy reform (Huber \& McCarty 2004, 2006). In addition, governance theories elaborate on the complex networks of administrative and governmental actors who shape the policy implementation process (Robichau \& Lynn, 2009). For this reason, the interplay between multiple actors across different levels of government should be well understood to determine their influence and control over the policy outcomes (Robichau \& Lynn, 2009). Thus, the engagement of the lower level bureaucrats should not be deemed insignificant in any policy implementation in Indonesia.

A strong legal and political mechanism must be in place and established by top-level policymakers. Well thought-through plans, goals and theoretical frameworks under- 
girding the policy should be clearly explained and shared with the relevant stakeholders. A policy tool that is often used in top-down approaches are mandates, and this tool is appropriate. Mandates are intended to guarantee compliance of all parties involved, but their significant downside is that their enforcement and supervision may be expensive (McDonnell \& Elmore, 1987). In most implementation cases, a task force or committee involving actors and stakeholders from both the top and operational levels is formed to implement policies (Brata, 2014). For the Equity and Access Policy, however, no new task force or committee was formed to oversee the implementation of the policy; instead, the responsibility of carrying out this policy was given to the DGHE in the MORTHE (Rahmawati, 2016). The use of mandates and having an enforcing agency responsible for carrying out the policy signals the extent of policy's importance to the top-level policymakers.

\section{Result and Discussions}

The Equity and Access Policy requires that one fifth of all students in Indonesia's HEIs are from the two bottom income quintiles, but that goal has not been achieved as of yet. Several initiatives have been pursued to ensure that this occurs. One of them includes adjusting the fee levels for undergraduate programs at public institutions outside of the toptier autonomous public universities. Four types of scholarship programs financially assist students with both fees and living costs. However, in 2014 , only $10 \%$ of students received scholarships or financial assistance, well below the $20 \%$ set by the government for that year. This section will discuss the political and institutional factors that might have impeded the implemention success throughout Indonesia. The implementation process will be evaluated against the blended topdown framework discussed earlier. A case study of one of the top-tier autonomous public institutions will be introduced to contextualize and exemplify the implementation of the policy.

The stakeholders, agencies and target groups of the Equity and Access Policy affect the policymaking and implementation process at different stages. Higher Education Law 12 from 2012 originated by order of the country's President, in line with the National Medium-Term Plan (RPJMN) of 2010-2014. This step was followed by a legislative order where the proposed law was signed by at least 10 members of the House of Representatives (DPR) (Republic of Indonesia, 2016). Once executed, it was then brought to the House of Representatives for discussion with special committees, legislation bodies and budgeting teams. These teams were responsible for finalizing all parts of the law, the implementation process and determining which departments and agencies will be responsible in carrying out the law. Special interest groups, business conglomerates and various private institutions often (indirectly) influence sections of the law at this stage (Retnoningsih \& Marom, 2014). This is usually done by lobbying the representative members involved in the process. Once the law is formally finalized, it is brought to the floor at the House of Representatives and put to the vote. If passed, it is signed by the President. The President reserves the right to make any final changes or veto any of the sections of the law. If changes occur, then the law is returned to the House of Representative for another vote.

The Law 12 of 2012 was successfully passed and signed by then President, Susilo Bambang Yudhoyono on August 10th, 2012. Both the MRTHE and the MRA are responsible for carrying out the law, with the DGHE overseeing and implementing the law within HEIs across Indonesia. The law itself was passed with relative ease as it was strongly 
supported by the President and the coalition of political parties in the House of Representatives (Rahmawati, 2016). The law underscores "a well-planned, guided and sustainable approach to HE governance" is a foundation to the "realization of social justice in access to HE that is of high quality", but also in the interest of "development, independence and prosperity" (Republic of Indonesia, 2012, p. 31). The top-tier autonomous public institutions also supported policy as it gave them more autonomy in the governance and operations of their universities (Brewis, 2016). Since the policy was not employed within private institutions, they did not voice their concerns about its potential implications. By evaluating the implementation process using the blended top-down approach, it is evident that the policy has a solid objective with an adequate theory of change underlying the policy, formulated by both the relevant bureaucrats and officials. The legal and procedural structure of the implementation process further ensured that all parties followed through because there is a clear policy mandate along with the DGHE overseeing compliance. The socioeconomic context and any related changes did not weaken political rationale and support for the policy particularly given that it was designed to help and meet the demands of those with lower SES status.

\section{a. Implementation Breakdown}

The implementation of the Equity and Access Policy seems to breakdown when the institutions attempt to set and enforce the regulations mandated to them. There were obstacles and tensions regarding coordination between the DGHE and the universities, both technically and management-wise because there was no direct regulation that pressured the university to implement this policy. When this occurs, any new policy finds itself in competition with other initiatives for the universities' limited resources. Individual players' interests and goals may further complicate the existing policy dynamics particularly if the policy is not aligned with the universities' strategic vision and agenda.

Any policy is dependent on political willingness to implement it as well as the capacity to do so, but the process also requires that parties involved be both pressured and supported during implementation (McLaughlin, 2009). Further, and in line with Foucauldian perspective (Sabic-El-Rayess \& Mansur, 2019; Foucault, 1997) on power being present in every context and action: "vague mandates and weak guidelines provide the opportunity for dominant coalitions or competing issues to shape program choices" (McLaughlin, 2009, p. 173). Most public institutions in Indonesia have limited resources; therefore, if DGHE's support was technically or financially limited, the local stakeholders would focus on other programs or policies in their institutions.

More importantly, there were no additional incentives or sanctions attached to the implementation of the policy. Tuitions in public institutions are determined based on income with the poor students being subsidized by the wealthy students' tuition (Retnoningsih \& Marom, 2014). The government, via the MOF, does not allocate additional subsidies to support more students from low SES backgrounds. The government only continues to provide the already existing merit-based financial aid programs. Additionally, no sanctions were imposed on the institutions if they did not achieve the policy's objectives, since institutions were only told to 'seek \& screen' potential students. In contrast to the affirmative action policies of higher education in India, for instance, there is no legal structure that secures representation of the poor in the HEIs (Boston \& Nair-Reichert, 2003). In other words, for a successful policy implementation, the implementation body should 
both pressure and offer support by using a combination of incentives and sanctions.

As of 2016, the enrolment rate for those in the two lowest quantiles of SES is still well below $20 \%$ and reported to be around $10 \%$ (DGHE, 2017). The policy has been in place for a few years, and serious concerns should be raised in regards to the efforts made by the institutions as well as DIKTI to achieve the $20 \%$ enrolment goal. The current implementation framework clearly lacks political and institutional commitment and skilled personnel coupled with limited 'push' from the power holders (Retnoningsih \& Marom, 2014). While Indonesia is officially a democratic country and has adapted a decentralized approach to governing, it is still very much centralized in practice. Local governments and its bureaucrats still lack capacity to independently govern and plan economic initiatives that would promote local economic growth, as evidenced in the local government's dependence on the support from the central government (Nasution, 2016). Students did not voice their concern or discontent about this policy, likely because they were not fully informed (Retnoningsih \& Marom, 2014). Also, when there are systematic failures that students observe in higher education institutions, their "voice mechanism [is] severely diminished in its power" so "students often remain passive, and if they voice their dissatisfaction, they do so less aggressively (Sabic-El-Rayess, 2014, p. 74)." The absence of interest groups is also noticeable, which means that they could not assist in the lobbying and accountability of the policy implementation at the institutional level. The lack of 'push' from the 'street-level' stakeholders along with the low capacity of those bureaucrats contributed to the Equity and Access Policy's implementation breakdown.

\section{b. Financial Aid Programs}

In this section, the study analyzes different types of programs implemented by public institutions in an attempt to provide financial aid to those who need it, and pinpoint to where efforts can be improved to guarantee that the goals and objectives of the policy are achieved. Over the past decade, the government has introduced several financial aid programs to address the inequity in access to higher education. A full scholarship program called BidikMisi started in 2010. This program has supported the academically strong but poor high school graduates during the entire 4-year-long bachelor degree or a 3 year diploma program. The demand for the BidikMisi program has constantly risen from 2010 to 2015 , however, the quota for students receiving these scholarships has not risen accordingly. Figure 3 shows the number of applicants (light green) compared to the number of scholarships available in the program (orange). The number of applicants increased by $600 \%$ from 2010 to 2014 while the number of scholarships has only risen by $300 \%$. Another financial aid program provided by DIKTI is BBM and PPA, and this program works to lessen the college dropout rate. The program works with poor students who have stellar academic and non-academic backgrounds measured by their high GPA or success in sports or arts and who attend either public or private universities (DGHE, 2017). 


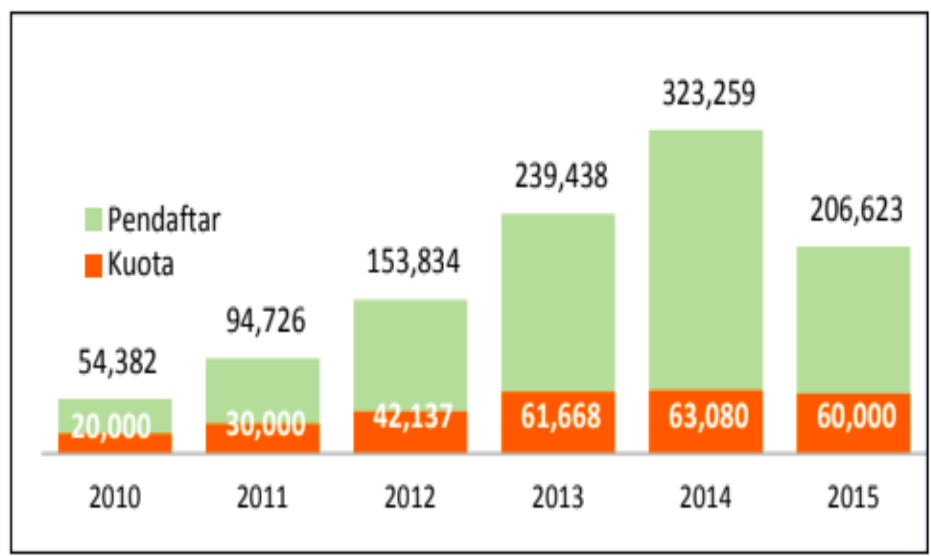

Figure 3. BIDIKMISI Scholarship Applicants

(Source: RISTEKBRIN, 2016, np)

Despite these efforts of providing financial aid programs that target the poor, institutions are still unable to meet the requirement of the policy. All of these financial aid programs are also designed to be merit-based while continued access to the scholarship requires students to have and maintain above average academic grades. Students who receive BidikMisi scholarships have demonstrated outstanding academic performance, around $75 \%$ have maintained a GPA of 3.0 and above (Figure 4). However, this requirement does not fully address the issue of equity in access for students, especially those from low SES backgrounds since most of them do not have access to the quality $\mathrm{K}-12$ education, therefore they are not academically ready to perform or meet the requirements set by the institutions. Given this context, there may not be a sufficient number of qualified low SES students to meet the requirements of having $20 \%$ enrolment in the institutions. It is possible that the institutions themselves are downsizing the applicant pool of students from poorer backgrounds due to the fact that these students would require more subsidies. This paper thus includes a case study of University of Gadjah Mada and examines their financial reports in order to understand their financing structure and their policy implementation efforts.

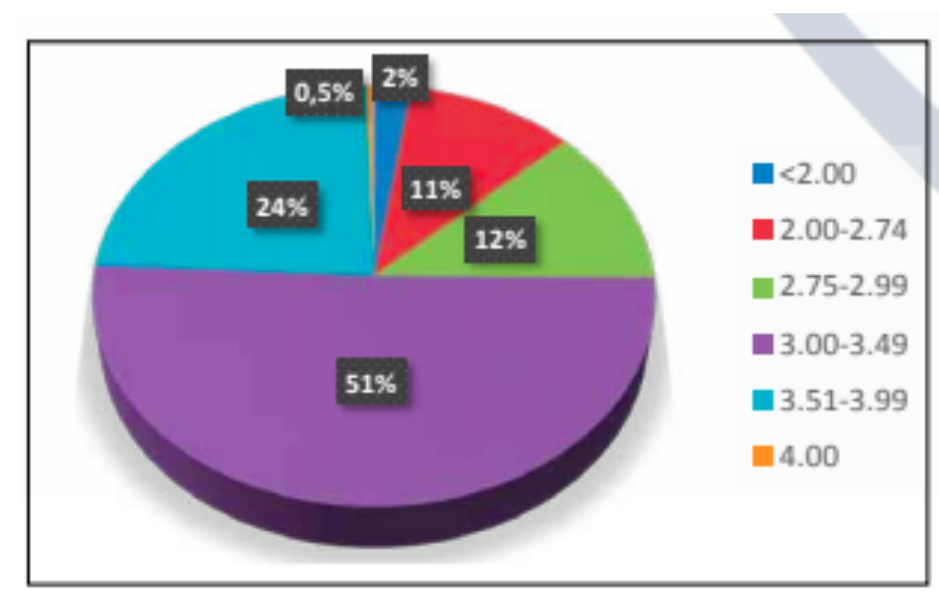

Figure 4. BIDIKMISI Scholarship Recipients GPA

(Source: RISTEKBRIN, 2016, np) 
c. Case Study: University of Gadjah Mada

Over the years, the University of Gadjah Mada (UGM) has worked to admit students based on merit while accounting for their diverse backgrounds. The institution first opened its doors in 1949, and since then has used its limited resources to lead the "affirmative action" effort and accept students nationally (Logli, 2015). About 50\% of the student pool is accepted based on standardized testing and another half is invited (University of Gadjah Mada, 2010). High schools suggest between 5 to 50 percent of their top graduates be admitted to UGM (University of Gadjah Mada, 2010). In spite of these efforts to diversify its student population, 83 percent of UGM's students still come from Java (Logli, 2015).

In Figure 5, the study includes the sources and uses of income for UGM from 2013-2016. Considering that the policy was implemented in 2012, it is evident that the funds used for financial aid programs have increased since then, indicating the institutional efforts to recruit more students who would receive scholarships.
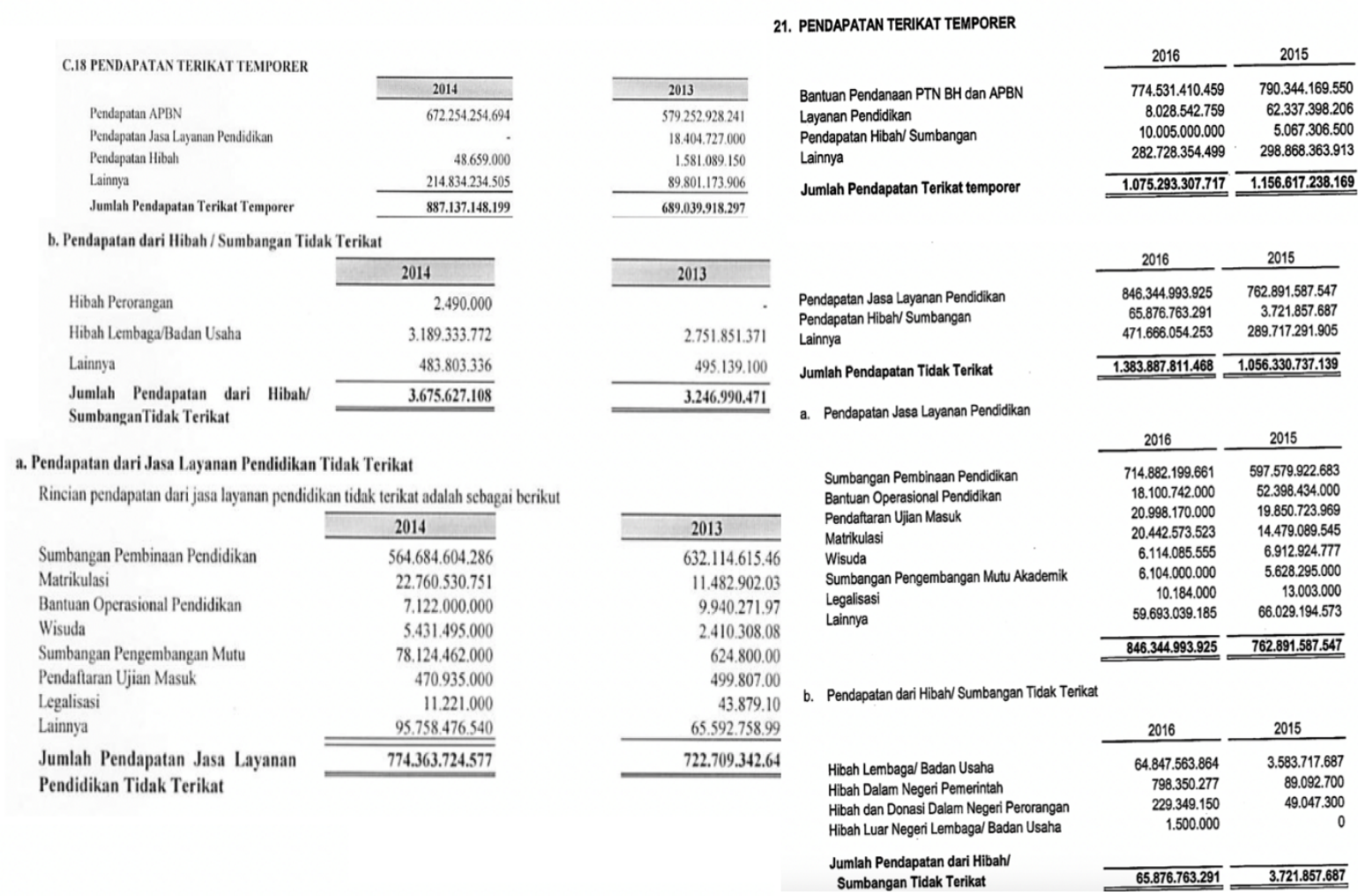

Figure 5. UGM Scholarship Income 2013-2016

(Source: UGM, 2016, p. 35)

The size of scholarship funds has steadily increased from 2013-2016 (Sumbangan Pembinaan Pendidikan) since the policy has been implemented and well above the years prior to the policy. However, the enrolment rate for students from low SES background has not risen accordingly. The number of low SES students has remained at around $10 \%$ even after the policy's implementation (University of Gadjah Mada, 2016). Therefore, it is possible that it does not matter how much the University intends to allocate to financial aid 
programs, but that there are not enough students from low SES to choose from as they are not meeting the admissions standards set by the universities. This may be occurring due to a limited number of students who qualify for scholarship funding in its current form, further pointing to the importance of the quality K-12 education. The existing discrepancy between the funds available and scholarship students is rather discouraging since the intent of the policy is to secure equitable access for those who need it most. In India, students from lower castes fill in all reserved seats for those castes and are provided remedial courses to support their success at the higher education institutions they attend (Boston \& Nair-Reichert, 2003). Currently, Indonesia lacks a systematic change to ensure that students from low SES backgrounds are academically ready and are able to meet the requirements of the institutions.

\section{Conclusion}

Indonesia's efforts to address the inequity of access of higher education, specifically to those from low SES backgrounds have been admirable. The policy of Law 12 Section 74 or the Equity and Access Policy was implemented to ensure that $20 \%$ of enrolment in all higher education institutions across Indonesia is made up of students from the two lowest SES quintiles. After careful examination of the implementation process, there seem to be two major faults in how the policy is designed and adapted at the institutional level. The first failure occurs at the institutional level where there are no direct regulations and mechanisms recommended by the DGHE that either give support or exercise pressure on the institutions to adopt the policy. The second failure is due to the design of the policy itself as the issue of higher education's inequitable access correlates to a similar problem of the lacking access to the quality K-12 schooling. The financial aid programs available at institutions to address the needs of low SES students are imperfect since the financial aid is often contingent on the academic achievement of the students when applying to the institutions and while they are enrolled in the institutions. Inadequate preparations and inequitable access to quality K-12 education greatly diminishes the pool of the low SES applicants from which institutions can choose.

Understanding the student background fully and holistically is critical in envisioning the adequate assistance for Indonesia's poor. To ensure equity and improve access for the poor, a systematic change is needed to assist those who are disadvantaged financially and academically in pursuing the post-secondary education. Affirmative action policies are crucial in bringing equity to those groups who have been continuously at a disadvantage. Specific provisions and policies must be implemented to assist institutions in seeking and supporting those students so that they are provided with the necessary support to enroll and study in the institutions. Additionally, institutions such as community colleges should be continually expanded throughout the provinces of Indonesia. Community colleges can be the social mobility vehicle that provides equitable access to the post-secondary education to those from low SES backgrounds as they provide 2 -year post-secondary education at a lower cost and are not as academically rigorous in their requirements. Securing broader access and growth in higher education and overall the education system is critical to developing Indonesia's human capital, but that will not occur without strong political will to decisively enforce policies on equity, inclusion, and access to higher education.

\section{References}

Addison, H. J. (2009). Is administrative capacity a useful concept? Review of the 
application, meaning and observation of administrative capacity in political science literature. LSE Research Paper.

Andayani, D. (2017). Resmi Ditutup KPU, 27 Parpol Daftar sebagai Peserta Pemilu $2019 . \quad$ Retrieved from: https://news.detik.com/berita/3686991/re smi-ditutup-kpu-27-parpol-daftar-sebagai-peserta-pemilu-2019.

Becker, G. S. (1964). Human capital: A theoretical and empirical analysis, with special reference to education. New York: National Bureau of Economic Research.

Becker, G. S. (1993). Nobel lecture: The economic way of looking at behavior. Journal of Political Economy, 101(3), 385409.

Boston, T., \& Nair-Reichert, U. (2003). Affirmative action: perspectives from the United States, India and Brazil. Western Journal of Black Studies, 27(1), 3.

Brata, R. A. (2014). Why did anticorruption policy fail?: A study of anticorruption policy implementation failure in Indonesia. IAP.

Brewis, E. (2016). Inclusive development in Indonesian higher education reform post1997, presented at the annual ASEASUK Conference, London, U.K., 2016.

Cam, T., \& Van Cao, T. A. (2008). Urban and rural dimensions of income inequality in Vietnam.

Dilas, D. B., Mackie, C., Huang, Y., \& Trines, S. (2019). Education in Indonesia. WENR: World Education News+ Reviews, on March, 21.

DGHE (Directorate General of Higher Education) (2017). Laporan Kinerja 2017. Kementerian Riset, Teknologi, dan Pendidikan Tinggi Republik Indonesia.

Doyle, C., \& Weale, M. (1994). Education, externalities, fertility and economic growth. Education Economics, 2(2), 129167.

Dynarski, S. M. (2003). Does aid matter? Measuring the effect of student aid on college attendance and completion. American Economic Review, 93(1), 279288.
Dynarski, S., \& Scott-Clayton, J. (2013). Financial aid policy: Lessons from research (No. w18710). National Bureau of Economic Research.

Elmore, R. F. (1979). Backward mapping: Implementation research and policy decisions. Political Science Quarterly, 94(4), 601-616.

Foucault, M. 1997. "The ethics of the concern of the self as a practice of freedom." In Michael Foucault ethics: Subjectivity and truth, edited by P. Rabinow, 281301. New York: New Press.

Gao, S. (2015). The measurement of tertiary education quality in Indonesia through the education production function model and policy recommendations for quality improvement (Doctoral dissertation, University of Pittsburgh).

Goldrick-Rab, S., Harris, D. N., \& Trostel, P. A. (2009). Why financial aid matters (or does not) for college success: Toward a new interdisciplinary perspective. In Higher education: Handbook of theory and research (pp. 1-45). Springer, Dordrecht.

Hartog, J., \& Oosterbeek, H. (1998). Health, wealth and happiness: Why pursue a higher education?. Economics of Education Review, 17(3), 245-256.

Hjern, B., \& Porter, D. O. (1981). Implementation structures: a new unit of administrative analysis. Organization studies, 2(3), 211-227.

Huber, J.D., \& McCarty, N. (2004). Bureaucratic capacity and legislative performance. In The Macropolitics of Congress, ed. E. S. Adler and J. S. Lapinski. Princeton, NJ: Princeton University Press.

Huber, J.D., \& McCarty, N. (2004). Bureaucratic capacity, delegation, and political reform. American Political Science Review 98(3):481-94.

ICEF Monitor (2014). Dramatic growth in Indonesia foreshadows greater demand for study abroad. Retrieved from: https://monitor.icef.com/2014/03/dramatic-growth-foreshadows-greater-demand-for-study-abroad-in-indonesia/. 
Kosasih, A. (2016). Rich in Natural Resources: Blessed or cursed? Retrieved from: https://www.globalindonesianvoices.com/26912/rich-in-natural-resource-blessed-or-cursed/.

Lipsky, M. (1980). Street-level bureaucracy: Dilemmas of the individual in public service. Russell Sage Foundation.

Logli, C. (2015). Bhinneka Tunggal Ika (Unity in Diversity): Nationalism, ethnicity, and religion in Indonesian higher education. PhD dissertation, University of Hawaii at Manoa.

Logli, C. (2016). Higher education in Indonesia: Contemporary challenges in governance, access, and quality. In The Palgrave handbook of Asia Pacific higher education (pp. 561-581). Palgrave Macmillan, New York.

McDonnell, L. M., \& Elmore, R. F. (1987). Getting the job done: Alternative policy instruments. Educational evaluation and policy analysis, 9(2), 133-152.

McLaughlin, M. W. (1987). Learning from experience: Lessons from policy implementation. Educational evaluation and policy analysis, 9(2), 171-178.

MOEC (Ministry of Education and Culture) (2013). Overview of the education sector in Indonesia 2012: Achievements and challenges. Retrieved from: http://perpustakaan.kemdikbud.go.id/opac/index.php?p=show_detail\&id $=34164 \&$ keywords $=$.

MOEC (2014). Indonesia's higher education system: How responsive is it to the labor market? Retrieved from: http://documents.worldbank.org/curated/en/596601468268792237/Indonesias-higher-education-system-how-responsive-is-it-to-the-labor-market.

Moeliodihardjo, B. (2014). Higher education in Indonesia. Jakarta: British Council.

Moratti, M., \& Sabic-El-Rayess, A. (2009a). Transitional Justice and DDR: The Case of Bosnia and Herzegovina. International Center for Transitional Justice, 6.

Moratti and Sabic-El-Rayess, A. (2009b). Research Brief: Transitional Justice and DDR: The Case of Bosnia and
Herzegovina International Center for Transitional Justice.

Nasution, A. (2016). Government Decentralization Program in Indonesia. ADBI Working Paper 601. Tokyo: Asian Development Bank Institute. Retrieved from: https://www.adb.org/publications/government-decentralization-program-indonesia/.

Negara, S., \& Benveniste, L. (2014). Tertiary education in Indonesia: Directions for policy. World Bank. Retrieved from: http://documents.worldbank.org/curated/en/105061468044074141/Tertiary-education-in-Indonesia-directions-for-policy.

OECD (2013). Structural Policy Country Notes: Indonesia. Retrieved from: https://www.oecd.org/dev/asia-pacific/Indonesia.pdf.

OECD/Asian Development Bank. (2015). Education in Indonesia: Rising to the Challenge. Paris: OECD.

OECD (2020). Secondary graduation rate (indicator). Retrieved from doi: $10.1787 / \mathrm{b} 858 \mathrm{e} 05 \mathrm{~b}$-en.

Prakhov, I. (2019). The Determinants of Expected Returns On Higher Education In Russia: A Human Capital Theory Perspective. Higher School of Economics Research Paper No. WP BRP, 50.

QS (2019). Study in Indonesia. Retrieved from: https://www.topuniversities.com/where-to-study/asia/indonesia/guide.

Rahmawati (2016). Implementasi Kebijakan Beasiswa Bidikmisi Tahun 2010-2014 (Policy Implementation Bidikmisi Scholarship year 2010-2014). Jurnal Ilmu Pemerintahan Undip, October 2016.

Republic of Indonesia (2010), National Medium Term Development Plan.(RPJMN/MTDP) 2010-2014, English Version, Book II, Chapter 2, Republic of Indonesia.

Republic of Indonesia (2012), Law of the Republic of Indonesia, Number 12 Year 2012 on Higher Education, Republic of Indonesia.

Republic of Indonesia (2016). Pembuatan UU. Retrieved from: 
http://www.dpr.go.id/tentang/pembuatan-uu.

Retnoningsih, Y.D., \& Marom, A. (2014). Analisis Kebijakan Penyelenggaraan Pendidikan Berbasis Uang Kuliah Tunggal Bagi Perguruan Tinggi Negeri Fakultas Ilmu Sosial Dan Ilmu Politik Universitas Diponegoro (Policy Analysis of Needs-based Tuition Fees in The Faculty of Social Science and Politics at the University of Diponegoro). Indonesian Journal of Public Policy and Management Review, 2017.

RISTEKBRIN (2016). Distribusi IPK RataRata Nasional Bidikmisi. Retrieved from: https://www.ristekbrin.go.id/infografis/distribusi-ipk-rata-rata-nasionalbidikmisi/.

RISTEKBRIN (2016). Peminat dan Daya Tampung Bidikmisi (2010-2015). Retrieved from: https://www.ristekbrin.go.id/infografis/peminat-dan-dayatampung-bidikmisi-2010-2015/.

Robichau, R. W., \& Lynn Jr, L. E. (2009). The implementation of public policy: Still the missing link. Policy Studies Journal, 37(1), 21-36.

Sabatier, P. A. (1986). Top-down and bottomup approaches to implementation research: a critical analysis and suggested synthesis. Journal of public policy, 6(1), 21-48.

Sabatier, P., \& Mazmanian, D. (1980). The implementation of public policy: A framework of analysis. Policy studies journal, 8(4), 538-560.

Sabatier, P.A., \& Mazmanian, D.A. (1989). Implementation and Public Policy. Landham, MD: University Press of America.

Sabic-El-Rayess, A. (2009). Internationalization in the educational system of a weak state:

examining multiple identities of Bosnia and Herzegovina's higher education. Intercultural Education, 20(5), 419-428.

Sabic-El-Rayess, A. (2011). Powerful friends: Educational corruption and elite creation in post-war Bosnia and Herzegovina. Research Brief.
Sabic-El-Rayess, A. (2012). Making of a voiceless youth: Corruption in Bosnia and Herzegovina's higher education (Doctoral dissertation, Columbia University). Retrieved from: https://academiccommons.columbia.edu/doi/10.7916/D8K361NJ.

Sabic-El-Rayess, A., \& Otgonlkhagva, S. (2012). School uniform cost reduction study: Standardization, simplification and supply Policy. Retrieved from: https://academiccommons.columbia.edu/doi/10.7916/d8-6e50-8257.

Sabic-El-Rayess, A. (2013). When corruption gets in the way: Befriending diaspora and EU-nionizing Bosnia's higher education. European Education, 45(2), 6-27. Retrieved from: http://etico.iiep.unesco.org/sites/default/files/ETICO000495.pdf.

Sabic-El-Rayess, A. (2014). Acting and reacting: Youth's behavior in corrupt educational

settings. Peabody Journal of Education, 89(1), 70-85. Retrieved from: https://sabicelrayess.files.wordpress.com/2016/04/acting-and-reacting2014.pdf.

Sabic-El-Rayess, A. (2016a). Merit matters: Student perceptions of faculty quality and reward. International Journal of Educational Development, 47, 1-19. Retrieved from:

https://files.eric.ed.gov/fulltext/ED5964 61.pdf.

Sabic-El-Rayess, A. (2016b). Who gets radicalized? What I learned from my interviews with extremist disciples. Retrieved from: https://academiccommons.columbia.edu/doi/10.7916/d8-c3p7-ke50.

Sabic-El-Rayess, A., \& Mansur, N. N. (2016). Favor reciprocation theory in education: New corruption typology. International Journal of Educational Development, 50, 20-32. Retrieved from: https://www.sciencedirect.com/science/article/pii/S0738059316300566.

Sabic-El-Rayess, A., \& Seeman, A. M. (2017). America's familial tribalism. Retrieved 
https://academiccommons.columbia.edu/doi/10.7916/d8-7jt8-mh87.

Sabic-El-Rayess, A., Mansur, N. N., Batkhuyag, B., \& Otgonlkhagva, S. (2019). School uniform policy's adverse impact on equity and access to schooling. Compare: A Journal of Comparative and International Education, 1-18.

Sabic-El-Rayess, A. (2019). Role of education in financial inclusion of poor and unbanked women in India. Indonesian Journal on Learning and Advanced Education (IJOLAE), 1(2), 72-90. Retrieved from: http://journals.ums.ac.id/index.php/ijolae/article/view/8413.

Sabic-El-Rayess, A. (2020). Epistemological shifts in knowledge and education in Islam: A new perspective on the emergence of radicalization amongst Muslims. International Journal of Educational Development, 73, 102148. Retrieved from: https://www.sciencedirect.com/science/article/pii/S0738059319306261.

Sabic-El-Rayess, A. and N. Mansur (2020). From educational displacement to replacement: Educational disengagement theory of radicalization, Working Paper.

Schultz, T. W. (1961). Investment in human capital [Presidential address delivered at the annual meeting of the American Economic Association, Saint Louis, MO, December, 1960]. The American Economic Review, 51, 1-17.

Schultz, T. W. (1981). Investing in people: The economics of population quality. Los Angeles: University of California Press.

Smith, K. B., \& Larimer, C. W. (2008). The public policy theory primer. Westview press.

Solmon, L. C. (1975). The relation between schooling and savings behavior: An example of the indirect effects of education.
In Education, income, and human behavior (pp. 253-294). NBER.

Tran, H. T. M. (2019). Women's health: a benefit of education in Australia. Health Education.

Turner, R. H. (1960). Sponsored and contest mobility and the school system. American Sociological Review, 855-867.

University of Gadjah Mada. (2012). Rekapitulasi mahasiswa S1 reguler baru, terdaftar, dan lulusan (Report on students in undergraduate degrees-enrolled and graduated).

University of Gadjah Mada. (2016). Rekapitulasi mahasiswa S1 reguler baru, terdaftar, dan lulusan (Report on students in undergraduate degrees-enrolled and graduated).

Van der Klaauw, W. (2002). Estimating the effect of financial aid offers on college enrollment: A regression-discontinuity approach. International Economic Review, 43(4), 1249-1287.

Welch, A. (2012). The limits of regionalism in Indonesian higher education. Asian Education and Development Studies, 1(1), 24.

World Bank (1998). Indonesia: Education in Indonesia, from Crisis to Recovery. Washington, DC: World Bank.

World Bank (2019). School enrollment, tertiary (\% gross) - Indonesia. Retrieved from: https://data.worldbank.org/indicator/SE.TER.ENRR?locations=ID).

Yulianto, A. (2017). The Implementation of Higher Education Autonomy in Indonesia: Problems and Challenges. European Journal of Research and Reflection in Management Sciences, 5(3), 39-50. 